\title{
A Rebellious Past: History, Theatre and the England Riots
}

\begin{abstract}
Alain Badiou has argued that the England riots of 2011, in dialogue with societal upheavals around the world that same year, demonstrated fundamental crises in our governing social, economic and political discourses. Whilst institutional responses to the riots treated them as an aberration, Badiou believes them to be symptomatic of a broader rebirth of 'history' - the coalescing of past and present events into a congruent trajectory with powerful implications for the future. Using Badiou's argument as a starting point, this article considers two theatrical responses to the riots - Nicholas Kent's premiere of Gillian Slovo's The Riots at the Tricycle, and Sean Holmes' revival of Edward Bond's Saved at the Lyric Hammersmith. By looking at the ways in which the productions sought to historicize the riots, I unpick both their interpretations of these events, and the contributions they were able to make to the urgent and ongoing discussions that the riots have generated.
\end{abstract}

\section{HISTORY AND THE ENGLAND RIOTS}

England in August 2011 saw the eruption of civil unrest on an extraordinary scale. What began as a series of protests over the killing of a civilian by the police force escalated to acts of mass looting, vandalism and arson that spread from London to cities across the country over the course of a week. The aftermath saw thousands of people arrested and imprisoned in line with a 'zero tolerance' policy implemented by the British Prime Minister, who labelled the riots 'criminality, pure and simple'. ${ }^{1}$ Whilst this policy granted legislative and judicial institutions the power to punish those involved, the bullish single-mindedness of its core sentiment could not account for the size and scale of the riots, nor their co-incidence with the range of public disturbances that erupted around the world that same year. In other words, the institutional responses to the riots tackled exceptional events without conceding their exceptionality, apart from where it increased their own capacity to administer punitive reprisals. An explanation for this irregularity was offered by the French philosopher Alain Badiou, who claimed that the England riots, in dialogue with global events such as the so-called Arab Spring and the French Austerity demonstrations, revealed deep-set malfunctions in the governing socioeconomic discourses:

Today, there are riots throughout the world, from workers' and peasants' riots in China to youth riots in England [...] What they all have in common is that they stir up masses of people on the theme that things as they are must be regarded as unacceptable. (21)

In responding to the England riots, the State (to borrow the term from Badiou) merely reasserted the authority of its institutions by using them to penalise those involved (26). This response avoided questioning why the riots had occurred because, according to Badiou, the answer would undermine the agency of the State at an ideological level, just as the physical irruption of the riots had undermined its agency at an operational level. So where the rioters had wrested authority from the State in their localised areas of rioting, a sustained enquiry into the cause of the riots would cast aspersions on the legitimacy of that authority itself. In both cases, it must be said, the undermining is

\footnotetext{
${ }^{1}$ See 'David Cameron the riots: This is criminality, pure and simple' in the Guardian, 9 August 2011, <http://www.theguardian.com/politics/video/2011/aug/09/david-cameron-riots-criminality-video>
} 
entirely negative. The riots were fuelled by bleak, directionless violence, whose lack of a coalescing purpose destroyed both the impetus of the events, and the value of any ideological challenge they could issue to the governing powers. And of course, once the riots had burned themselves out, the State was left unopposed to reassert its control with acute ferocity.

Despite conceding this essential nihilism of the England riots, Badiou finds within the very fact of their exceptionality 'if not the possibility, then the possibility of a possibility' of some kind of collective public resistance to the inequities of a dominant order, 'so that the individuals they engage can give rise [...] to a new figure of organization and hence of politics' (42). That the riots have occurred at all indicates that 'the existing society, which is always a state organisation of Capital, does not possess the means altogether to prevent the advent of an historical sign of rebellion in the desolate spaces for which it is responsible' (26). The difficulty, for Badiou, is finding a way in which the urgent problems indexed by the riots may be addressed without being engulfed by those events' impotent self-destruction. In order to achieve this, he proposes that certain conditions must be implemented. Foremost amongst these conditions is a 'powerful concept or durable organization', or what he calls the 'rebirth of History, as opposed to the pure and simple repetition of the worst' $(5,6)$. This assertion warrants careful attention. 'History' in this case describes an interpellation of present and past events within a coherent structure capable of pursuing political objectives into the future. This produces what he calls a sequence, an interrelated chain of historical occurrences that open up the possibility for radical change by historicizing the present and affirming that things are not always as they are now; that this is not the only way to be. It is only by reinstating this concept, for Badiou, that our 'cyclical crises' of social and economic inequality may be overcome (10). The problems with this kind of purpose-driven teleology are numerous, and have been urgently set out by John Gray, whose Black Mass (2007) makes an impassioned case against the catastrophes that such entities' rigid inflexibilities produce. I have written a detailed response to these objections elsewhere (Haddow: 275288). Here, I will venture only that in isolation, a riot may be quashed, but this does not lessen the destruction it causes, nor does it address the reasons for its irruption and help to prevent its reoccurrence. Situated within a constellation of equivalent events, however, the implications of that riot may be more clearly perceived, and its significance better understood. Without that contextualisation, the mechanics remain concealed and the riots are paradoxically dismissible as an aberration, where at the same time the intensification of their conditions works to ensure repeated occurrences of rioting. A consideration of the riots must therefore be grounded in a clear appreciation of history, so as to offer the possibility of a 'genuine exit' from malfunctions in the established order. Otherwise, our perspective remains trapped in the present operations of our state apparatuses, which seek to maintain the situation that led to the riots in the first place.

Bernard Stiegler takes up a similar theme by reading the recent riots around Europe as the products of hyper-powerful economic structures in which increasingly vast numbers of people have no stake, coupled with an irresistible realisation that we are at 'the limits of this global [terrestrial] system'. This combination, for Stiegler, 'will only increase to apocalyptic levels if industrial democracies do not take radical measures' (2013: 48). Stiegler also turns to an idea of the historical by viewing anti-establishment riots throughout the $20^{\text {th }}$ and $21^{\text {st }}$ centuries as 'political, economic and social symptoms of capitalism's loss of spirit' (2014: 2). Rather than being 'criminality, pure and simple' - the manifestation of some freak collective delinquency - Stiegler sees the riots as the culmination of an evolving economic process that stretches back to the industrial capitalism of the eighteenth and nineteenth centuries. In both Badiou and Stiegler's work, the drive to historicize the irruption is born from a broader concern at the question of what happens next. Without this historicizing, the irruption is again dismissible as a present-based aberration which, of course, was exactly the way that most politicians in the UK defined the England riots. But, to continue Stiegler's metaphor, failure to recognise the symptoms as indicative of a broader disease allows that disease to 
spread unimpeded. If we are to address the disease, then a reconceptualization is required across all modes of critical engagement, with a commitment to history at its core.

The intention of this article is to draw these questions concerning history into a dialogue with two high-profile responses to the England riots that took place in the field of theatrical performance. Various rationales underpin this endeavour, but primarily I want to engage with an assumption, popularised in countless forms since Aristotle, that theatre possesses a potential to clarify principles of human endeavour that are otherwise somehow ungraspable. 'We must all do theatre', as Augusto Boal said in his habitually impressive fashion, 'in order to discover who we are, and who we might become' (62). In a similar (though less grandiloquent) vein, Nadine Holdsworth champions theatre as a form of 'cultural witnessing' specifically valuable to the consideration of riots, where the medium's 'temporal distance' can affirm the magnitude of these transitory events long after the news industries have lost interest (2010: 43). This question of 'temporal distance' inflects significantly, though in markedly different fashions, with the two productions I will examine here. These are; Gillian Slovo's specially commissioned verbatim play The Riots, directed by Nicholas Kent at the Tricycle Theatre, and Sean Holmes' revival of Edward Bond's Saved at the Lyric Hammersmith, both staged in October 2011. The two productions approached the riots in radically different ways, but what they shared in common was an attempt to rationalize these events through or as history. In Slovo's case, this was by exploiting the popular methods of verbatim theatre to create a piece of performed historiography, one whose legitimacy she and Kent sought to establish upon its capacity to relay testimonial material concerning the riots to the audience. In the case of Saved, Bond and Holmes drew upon the history of the play itself, and the timeliness of its 50 year old analysis of societal deprivation, in order to suggest connections between the riots and an older set of circumstances. Both productions thus commented on the riots by laying claims, in very different ways, to senses of 'history', and it is these senses that I will endeavour to unpick.

\section{SAVED AND THE RIOTS}

When asked why he had lifted his 27 year embargo on London productions of Saved for Sean Holmes' staging at the Lyric Hammersmith in October 2011, Bond replied that when he wrote the play he was pointing to the future, but that 'the future is now here' (Guardian, October 9, 2011). As he outlined in a new introduction to the printed text, what he meant by this 'future' was a widespread dissatisfaction and alienation amongst the lower economic strata of society, which he saw as being violently expressed in the riots (2012: 2 - 3). For Bond, the riots were an ignition of the 'atavistic fury' he had identified when writing his play; disaffection arising from a consumer culture that 'destroys the motive to be human' and robs individuated subjects of their collective identity (Spencer: 31 - 33). As Bond saw it, it was this disindividuation that had pushed societal tensions to the plundering and destruction of the riots themselves. Saved, through a fictional narrative, seeks to illustrate both the conditions of this disindividuation and the appalling consequences that it can produce; predicted in 1965 and apparently fulfilled in 2011. Provisionally, Bond's diagnosis of the riots aligns with those of cultural theorists Zygmunt Bauman, who labelled them 'consumerism coming home to roost', and Slavoj Žižek, who saw them as a demonstration of the 'material force of [capitalist] ideology' (Baumann 2011; Žižek 2011). Both Bauman and Žižek however, viewed the riots as a 'zero-degree' protest operating outside of all recognizable spheres of articulation, where Bond insisted on a historical approach in which appreciation of ' $[t]$ hen, now and to be' was imperative in comprehending the riots' overarching significance. This insistence was expressed in explicitly theatrical terms, as Holmes' revival of Saved reconfigured the concerns of a pre-existent text in dialogue with its performing context in order to historicize the present moment.

Concurrent with Holmes' production of Saved, the Tricycle theatre in Kilburn premiered Gillian Slovo's The Riots, a verbatim play assembled as a response to the same events and billed as a 
replacement for the public inquiry which ' $[\mathrm{t}]$ he government refused to hold' (Slovo: jacket material). Unlike Holmes' production of Saved, this piece directly intervened in the present moment and sought, through a process of documentation, to function as a piece of historiography. At one level, Slovo's dramatic text took sourced documentary material and converted it into what Roland Barthes would have called 'historical facts' - misleadingly verifiable indexes to past events - which Kent's production then translated into performance (Jenkins: 121). According to Slovo, the intention was to facilitate the audience's experience with a range of perspectives in the hope that spectators then, rather problematically, 'understood what was going on in our society in a way that allow[ed] them to have a voice' (Theatrevoice, November 9, 2011). The notion of 'giving' voices to the voiceless is something that has been repeatedly and irretrievably destabilised, particularly in the disciplines of postcolonial studies, with Gayatri Spivak contending that the identification and attempted 'voicing of the voiceless' is an emasculating ventriloquism on the part of those who 'seek to represent themselves as transparent' $(255,257)$. For Slovo, who staked the legitimacy of her project on its ability to act as a conduit for historical material, rather than on analysis of that material, transparency was a principal boast. Apparently believing this ability to be something accessible through transparency, both Slovo and Kent then publicly declared a lack of bias to their work, thus arguing that they could help audiences uncover 'the truth' behind the riots. This claim was strengthened by the Tricycle Theatre's historical reputation for producing successful verbatim dramas based on existing court cases and inquiries, where the apparent neutrality of the playwrights (or 'editors') has been valorised. ${ }^{2}$ The identification of the 2011 England riots as an event worthy of - even demanding - an inquiry was met with a measure of public approval, as some reviewers indicated. ${ }^{3}$ Slovo and Kent's project, which employed a theatrical form out of a production house both historically known for reproducing existing inquiries and tacitly constructing their own, was thus lent significant contextual weight. ${ }^{4}$

Both Saved and The Riots assessed the societal upheavals of August 2011 as critically significant, seeking in different ways to address the nature of (and therefore necessary response to) this significance, and both in different ways turned to history as a vehicle for their arguments. My analysis will lead me to suggest that the strategy used by Slovo and Kent - responsive, purportedly transparent and non-ideological - precludes the capacity for a committed engagement with its subject, and by eschewing broader historical discourses in fact resonates with the kind of supposedly 'postideological' agendas espoused by Francis Fukuyama in his 1992 polemic The End of History and the Last Man. Turning to Badiou and Jacques Derrida's separate critiques of Fukuyama's position, I move to suggest that the idea of history that underpins The Riots is insufficient to meet the demands of the performing context. By way of initiating a response, I will argue that Bond and Holmes' approach, abjuring 'objectivity' in favour of critical engagement, exploits its politicised perspectives to assert a more historically fertile analysis.

\section{THE RIOTS: REPRODUCING OTHERS}

In composing The Riots, Slovo conducted interviews with community leaders, policemen, politicians, London residents and people who had been involved in rioting. She transcribed, edited and arranged these testimonies into a dramatic text intended to 'ask the questions and provoke the thoughts' that she and Kent felt had been overlooked by the government's decision not to open a public inquiry

\footnotetext{
${ }^{2}$ For a high profile example of this, see Norton-Taylor, R. (1999) The Colour of Justice: Based on the transcripts of the Stephen Lawrence Enquiry, London: Oberon Books.

${ }^{3}$ See Stoller, T. (2013) Tales of the Tricycle Theatre, London: Bloomsbury Methuen Drama (186 - 191).

${ }^{4}$ In the latter cases, see Brittain, V. and Gillian Slovo (2004), Guantanamo: Honour Bound to Defend Freedom, taken from spoken evidence, London: Oberon, and Norton-Taylor, R. (2007), Called to Account: The Indictment of Anthony Charles Lynton Blair for the Crime of Aggression Against Iraq, London: Oberon; both are 'tribunal plays' invented by their authors, and premiered at the Tricycle.
} 
(BBC Front Row, November 21, 2011). The text consists of reproduced, edited and interwoven testimonies, and in a standard convention of British verbatim drama, these are designed to be performed by actors straight to the audience, giving the illusion of direct contact. The play's first act undertakes a chronological swoop of blow-by-blow accounts of the events immediately preceding riots 'as they took place', before settling down in the second act to a collage of perspectives offering posthumous commentary and analysis.

Kent's 2011 production began with a pre-set of text-messages and twitter feeds, followed by a short film of footage taken from across the four nights of rioting. These were projected onto a set of artfully slashed industrial fabric, breeze blocks and a DIY mise-en-scene: chairs, tables and a couple of crates of beer. Before the production proper commenced, two gunshots rang out across the auditorium. The shots indexed the murder of Mark Duggan, a 29 year old from Tottenham who was killed by the police. Immediately following this, two unidentified 'rioters' dressed in hooded jumpers and scarves appeared on stage and introduced Slovo's narrative by giving brief 'matter-of-fact' statements 'as if they were disembodied voices' (7). Their testimonies related directly to Duggan, whose murder, and its subsequent mishandling by the police, are proposed within the play as the act that set the events leading up to the riots in motion - translated, in other words, into a historical event. In the printed script, the directions for the two men are revealing:

\section{MAN 1 and MAN 2 on stage but they cannot be clearly seen. It is almost as if they are disembodied voices. They are rioters and, like MAN 3, who comes later, they should be separated from the rest of the characters. They are Other. A world apart from the audience. (7)}

In a recent survey of British plays that have responded to riots, Nadine Holdsworth advocates theatre's ability to overcome the dehumanising 'otherness' into which rioters - them - are often grouped by the $u s$ of popular discourses (2014: 91). She argues this ability through a complex of factors such as 'temporal distance', audience engagement, and the capacity to re-embody individuals who would otherwise be reduced to 'nameless, faceless statistics' (81). Set against Holdsworth's encouraging (and brilliantly conveyed) valorisation, however, the above stage directions raise troubling questions about the ways in which rioters as 'others' are appropriated in Slovo's play.

At one level, Slovo could simply be addressing the unknowability of her subjects - after all, these are people whose testimonies cannot be openly attributed for fear of punitive reprisals, so they are in a very physical way 'separate' both from the other voices in the text (whose identities are publicly acknowledged) and the assumed audience, whom the text takes every pains to stress have, (are being given), an identity. Holdsworth points out that Slovo found the rioters 'almost impossible to reach', and that she supplemented her own research with documentary interviews, social media posts and publicly available images and films (92). Yet for all of this, the majority of rioters' testimonies are abrupt and (necessarily) anonymous. 'They' are thus consigned to a predominantly offstage and indistinct presence, precisely the homogenous 'Other', in fact, that Holdsworth wants to counteract. What is more, the dearth of rioters' testimonies shifts the greater focus of the play onto the events that immediately preceded the riots, and then to post-mortem opinions and responses. The events around which the play revolves are beyond the remit of the text, a space overlaid with perspectives but which remains for the most part untraversed. This is never more apparent than when the interviewees are asked to describe the rioters in three words - a gimmicky but rather unproductive touch, whose principal consequence is to highlight the disparity in their responses. For Iain Duncan Smith, for example, the rioters are 'Dysfunctional, criminal and lost'; for Stafford Scott they are 'Frustrated, angry and British'; whilst 'Former Young Mayor of Lewisham' Jacob Sakil calls them 'The walking dead' $(55,60,34)$. Where these summations appear in the text, they are often at the closure of a 
subject's testimony - the last word - repeatedly reducing the rioters, and the riots, to the status of unknowable Others.

At another level, it could perhaps be argued that Slovo is playing upon popular conceptions of the rioters as others in order to highlight the futility of considering them as such. ${ }^{5}$ However, such a level of sophistication in constructing the text would counteract the transparency and objectivity with which she claims to have approached the project - the audience members are not there to have their opinions critiqued or pilloried, but rather to have the facts of the matter laid out for their informed and well-reasoned scrutiny. This may then mean that the play itself takes the position that the rioters are in fact Other, and are a world apart from the audience - although if this is the case, then the text is making some rather troubling assertions and presuppositions, and again this would counteract the professedly unbiased nature of the project. Taken together, all that can be deduced with any certainty is that there is a tension operating at the heart of Slovo's praxis, where her protestations of objectivity and transparency appear to be hampering and even subverting the analytic or critical potential of the text itself.

The rest of the production's first act dramatized a series of testimonies from community leaders, youth workers, police officers and - crucially - Mohammad Hammadoun, a man whose home was destroyed in the fires set by the rioters. Hammadoun, whom the stage directions indicate 'should be separate from the rest of the cast', is alone amongst the voices populating the first half in that he did not become involved in the riots as a result of any personal or professional compulsion: he simply happened to be living above Carpetright in Tottenham, which was burned down on the first night of the disturbances. His testimony largely concerns removing his two young children from the burning building, attempted conversations with the 'young people in Palestinian scarves' who were alternately assisting with the building's evacuation and 'throwing tyres into the fire t-to make it fuel even more', then finally laughing at the surreal nature of the event $(26-28)$.

Hammadoun's voice did not simply stand apart from the others recounted in the performance: he was proposed as a mediator, an entrance point for spectators - confused, concerned, but unwilling to express contempt or disregard. Slovo herself had already predicted Hammadoun before she encountered his 'story' - in interview, she informed Kirsty Lang that:

I think that there, it was clear to me from the beginning, that we needed to hear from certain people, in particular I think we needed to hear from a victim, of the riots, and we needed some rioters, we needed some police, and out of those central... people... I built the story around them of the others...

(BBC Front Row, November 21, 2011)

In other words, Hammadoun was cast in a role that Slovo had already imagined prior to the construction of her text. From a writerly point of view, this makes perfect sense; the narrative requires the voice of someone on the receiving end of the disturbances, a human face for the historical events being described. Pragmatically, her candidness addresses itself quite logically to the process of producing the play. She had been directly commissioned by Kent, who had called her whilst the riots were still underway, to write a play about these events. Approaching the issue as a writer, she had been required to identify the most likely sources of useful perspectives for her material. Her willingness to ascribe the term 'victim' to a subject may be in bad taste, but it is certainly not detrimental to her praxis - though of course this raises questions about that praxis itself. If she is approaching the issue with a narrative predetermined even to the extent that it delineates particular character types, how does this affect her protestations of objectivity? She is even blatant in her

\footnotetext{
${ }^{5}$ See, for example, Alecky Blythe's televised verbatim project The Riots: In their own words, BBC2, August 13 - 14, 2012. <http://www.bbc.co.uk/programmes/b0113y0v> [Accessed 26 February 2014].
} 
admission - 'I built the story' - a statement as unavoidable to the job she undertook as it is condemning to the rationale that both she and Kent proposed. In other words, Slovo's adherence to narrative structures militates against her supposed fidelity to 'documentary fact' because she is creating a 'story' that manipulates those 'facts' to suit an exterior purpose. In her own accounts, however, Slovo often appears unable to own up to this manipulation, preferring instead to offer avowals of objectivity that, as I have argued, do not bear up under scrutiny.

In her conversation with Slovo, Lang queried whether The Riots was a piece of journalism. Despite the fact that many of the protestations to objective reportage she makes concerning her praxis appear congruent with journalism, Slovo came out against the idea of a shared practice (like David Hare elsewhere), ${ }^{6}$ although her defence rested somewhat shakily on The Riots being a play and not journalism because it is 'a play length', 'has paying audiences' and 'uses actors' (BBC Front Row, November 21, 2011). Kent was a little more careful, pointing to the comparative speed of the two disciplines as opposed to more openly fictional drama, locating his conception of verbatim within an idea of committal and response, but never directly linking it to journalism. Mary Luckhurst has elsewhere advanced an observation on the reluctance of verbatim theatre to connect itself to journalism that expands upon Richard Norton-Taylor's increasing use of his own verbatim plays to redress inscrutably motivated omissions in popular press coverage or to critique problems in/with journalism itself: '[T]he reasons for the apparent 'explosion' of verbatim theatre in the west are complex and seem to be bound up with a widespread suspicion of governments and their 'spin' merchants, a distrust of the media and a desire to uncover stories which may be being suppressed' (Holdsworth 2008: 200). The irony here is that, in their attempts to 'uncover' the truth behind the riots and escape the manipulations of 'spin', Slovo and Kent have employed strategies that obscure their conceptions of 'truth' behind notions of transparency that are always irretrievably 'manipulated'.

\section{SAVED: REWRITING OTHERS}

The fictional narrative of Saved famously concerns a group of men and women in an impoverished, inner-city area. What begins as a meditation on youthful boredom expands into a critique of what David Ian Rabey calls the 'deadening of humanity amongst its futureless city dwellers', and its depiction of its central characters' dissolving relationships includes some of the most iconic scenes in contemporary British theatre (107).

In accordance with the stage directions, Holmes' production was staged on a mostly featureless white set, and whilst period details such as costumes and furniture were observed, the 'blank' nature of the setting offered the production a temporal flexibility, enabling it to straddle a range of contexts simultaneously. The flexibility was important to Holmes because, as he argued, if Saved is presented as a period piece, then the audience is distanced and protected from the play's essential 'shock' (Guardian, October 9, 2011). Dan Rebellato underlined the significance of the 'bare, off-white stage' as a canvas for the uncluttered presentation of (echoing Boal) 'who we are and who we might be' (Rebellato 2011). The set thus provided space for a dialogue between the past, present and future resonances of the play's diagnosis of societal violence. This sense of not being bound only to the past of its original production was supported by Bond: 'Laurence Olivier said that Saved was a warning about what will happen. The play is more relevant now than when I wrote it. I'm absolutely certain of that' (The Telegraph, September 30, 2011).

The blankness was doubly arresting given the absence of absence in the assumed spectatorship. This was not a production which - as many reviewers noted - it was easy to attend without preconceptions. What Marvin Carlson would call the 'ghosts' of past productions littered the on-stage

\footnotetext{
${ }^{6}$ See David Hare's interview in Will Hammond and Dan Steward, ed. (2008), Verbatim Verbatim, London: Oberon Books, (62).
} 
proceedings, and were even echoed offstage, in the hysteria of Quentin Letts' outraged review (Daily Mail, October 13, 2011). Saved had become a history play, but of a rather peculiar nature as it showed a world entirely annexed from a sense of past or future. As mentioned earlier, this annexation is critical to the play's argument, as it fosters a frustration that inexorably gives way to violence -the same principle that Badiou calls 'the repetition of the worst' where a durable sense of historical progression is suppressed (6).

A notable factor of Holmes' production was its demonstration of the ways in which this frustration can saturate the fabric of everyday life - as for example the following exchange, which occurs midway through Scene Four:

PAM: I don't understan' yer. Yer ain't got no self respect.

LEN: You 'ave like.

PAM: No one with any self-respect would wanna stay.

LEN pours tea for himself.

Yer'll 'ave t'go sometime. Yer can't juss 'ang on till yer rot.

MARY: Pack it up! No wonder that kid cries! (33)

This spat was performed against a gratingly loud soundtrack of a baby's wailing and each character faced the audience, locked within their own rigidly defined circles of attention and unwilling (or unable) to directly engage with one another. The preoccupation with 'self-respect' is significant, as this is the exact quality whose absence is identified by Bond as the motive underpinning the play's iconic depiction of infanticide. Both Len and Pam are mired in the same suburban doldrums, presided over by a middle-aged couple who have devoted their lives to each other's mutual destruction. Yet Pam taunts Len because he stays from choice, which gives him responsibility for his actions and indicates a lack of self-respect: why would one choose to remain in a situation where one is humiliated? Implicit in this taunting, of course, is the desperation felt by Pam herself, and an equivalent realisation of a lack of choice that indicates, ultimately, the eradication of even the possibility for her own self-respect. The situation is exacerbated by Mary, who capitalises upon her double role as both mother and grandmother in order to admonish Pam and Len for their aggravation of the baby. The admonishment is insincere, because Mary does nothing to assist the child, invoking 'it' simply as an instrument to serve her own interests. These, given that Mary actively participates in the construction of a hostile household, are not the resolution of conflict in order to create a secure environment, but rather the aversion of that conflict which is not hers in order to resume the insecure environment that is her proper co-dominion.

Complex distributions of power are unearthed by this exchange. At one level, for example, this is a battle over the political division of space. Embittered by her incarceration within the domestic environment, and the impossibility of self-respect that she sees as a natural consequence of this, Pam takes her frustrations out on Len. Thus, she taunts him with his relinquishing of what she herself has either lost against her own will or (more likely) never possessed in the first place. Mary then uses the conditions of Pam's incarceration (the baby) against the pair of them, awarding herself the pyrrhic distinction of prisoner-in-charge. What is notable, as with all of the hierarchical disputations in Saved, is the absence of any figures of actual power and authority. Apart from the invisible guards who contain Fred within his cell and control the flow of visitors he receives in scene eight, every character here is roughly in the same situation. They are Rabey's 'doomed, futureless city-dwellers', and Bond's interests lie in the ways in which ideology is perpetuated amongst and by these doomed individuals as a tool for their own oppression. All of which, in Holmes' revival, had profound implications for one of the more perplexing qualities of the riots. This was the attacking and looting of the rioters' own neighbourhoods, rather than neighbouring districts housing wealthier, more powerful people. Bond was not slow to point this out: 
Those girls out there, those guys - were they acting politically? You have to say "No - they don't understand their political situation". They didn't find out where the bankers are living - they turned on their neighbours. They started destroying themselves - and that's what happens in this play. The guys kill the baby in order to gain their self-respect. That seems like a total contradiction. That baby is dirty, inarticulate, unable to control its situation. (Telegraph, September 30, 2011)

Fifty years after the play's premiere, the riotous context of the revival at the Lyric Hammersmith seemed to validate Bond's prediction. Saved, as is well known, had at its author's insistence been absent from professional London stages for 27 years, and whilst Bond's rescinding of this embargo was informed by a professed faith in Holmes' abilities as a director, he also capitalised upon its timeliness in accordance with the recent upheavals. Throughout the promotional material for Holmes' production, Bond made repeated assertions about the relevance of Saved to the events and implications of the riots (BBC News, October 20, 2011). In his programme notes, an impassioned appraisal of the contemporary political situation is signed off with the following claim:

We have not yet seen the inflated arid trauma of nihilism practiced on a modern democracy: reality will hallucinate. The gilded parchment rhetoric will go. The violence will come out of their fear. They will be so afraid they would bury the dead in straightjackets. They have stamped out the fire to put it out - they have stamped it underground. (Bond: 2011)

Alongside an analysis of the volatile instabilities of the ideological landscape, what surfaces here is Bond's steadfast attention to the production of history. The dead (the past) are being straightjacketed to curtail their revolt; all that is present (the visible fire) is stamped underground, where its invisibility only intensifies the danger that it poses. The fire has not gone, but it can no longer be seen, as it operates somehow beneath the present. Bond's prediction proved to be eerily prescient - annexed from all historical understanding, the England riots became for the Right a symbol of 'criminality, pure and simple' and for the Left a consequence of the dismantling of public welfare services. ${ }^{7}$ Neither position, as Žižek pointed out, could be used to offer an explanation of why the riots took place. This granted them a renewed sense of terror - the terror of the inexplicable, in which the riots and the rioters were cast as a vast and monstrous Other.

It was into this condition, where all dangerous material had been annexed from the present to the past, where the implications of societal ruptures were manifested as dread since they were devoid of understanding, that Saved received its first London revival for almost quarter of a century. Bond's explanation for his refusal to allow London theatres to produce the play has remained consistent: we do not understand it. As with Boal and Rebellato, the business of drama is seen as no more nor less than the business of being human. For Bond, however, the term 'humanness' is far more complex, signifying a fundamental need to reconcile ourselves, both singly and collectively, through drama: '[w]e are made not by our reason but by our need to dramatize ourselves and our situations. In drama reason and imagination elucidate each other. This enables us to understand ourselves and what we do' (2000: 1). Thus, in order to 'understand' Saved under the conditions of dramatic enterprise as Bond defines them, we must consider the opportunities it provides us to recreate humanness. In doing so, Saved may be used to expand pragmatically upon the points that Badiou is raising about the need for a rebirth of history. Or, as Bond puts it '[d]rama fashions our consciousness. All great civilizations

\footnotetext{
${ }^{7}$ See 'Reading the Riots', a collaboration between the Guardian and the LSE, < http://www.theguardian.com/uk/series/reading-the-riots > [Accessed 25 November 2013].
} 
create the drama that sustains them. And a civilization is created when it comes to terms with its past' (2012). Inability or unwillingness to come to terms with that past, for both Badiou and Bond, amplify the conditions of a crisis point that returns us only to the inescapable nihilism manifested by the riots.

\section{COMPETING HISTORIES}

The differences between the historical strategies underpinning these two productions start to indicate a kind of divergence. In the case of The Riots, Slovo and Kent are aiming for an 'instant' history, assembling contextually specific materials in order to reproduce, as rapidly as possible, a facet of the contemporary world which may then be shown back to its inhabitants. Bond and Holmes, on the other hand, employ a sequential approach to history, identifying and asserting a pattern with historical precedence, in order to mount an argument about the forces at work within the modern world, rather than depicting a function of its exteriority by attempting to represent 'the facts'.

In order to break down these approaches and gain a sense of their political significance, I want to return to Badiou's argument that the upheavals of 2011 signalled the potential for a 'rebirth' of history. For this rebirth to happen, Badiou says that the 'modern world' has to die, citing Francis Fukuyama's infamous contention that the principles of neoliberalism will culminate in the 'end' of history (1992: xii). For Fukuyama, the dissolution of Soviet communism dismantled what he called 'totalising historical discourses', and in their place we were left to 'raise directly and explicitly the nature of the trans-historical standards by which we evaluate the goodness and badness of any regime or social system' (139). This supposed flattening of ideologies opened up a terrain in which Fukuyama argued that 'the only coherent political aspiration that spans different regions and aspirations around the globe' was liberal democracy, powered by its capitalist economic structures. These structures were conceived as universal; the 'trans-historical' standard by which the 'goodness' or 'badness' of all other systems could be judged, and were therefore conceived as being exterior to all other 'social systems'.

There have been a range of attacks upon this argument over the past two decades, and Fukuyama himself has rescinded many of his original statements. Belief in the possibility of a non-ideological platform for subsequent analysis may still be seen, however, in the verbatim practices I have discussed in the course of this article. As such, it is necessary to turn to Jacques Derrida, who offers the following comprehensive rebuttal to Fukuyama's argument:

with the one hand, it [Fukuyama's argument] accredits a logic of the empirical event which it needs whenever it is a question of certifying the finally final defeat of the socalled Marxist States and of everything that bars access to the Promised Land of economic and political liberalisms; but with the other hand, in the name of the transhistoric and natural ideal, it discredits this same logic of the so-called empirical event, it has to suspend it to avoid chalking up to the account of this ideal and its concept precisely whatever contradicts them in such a cruel fashion: in a word, all the evil, all that is not going well in the capitalist States and in liberalism, in a world dominated by other forces whose hegemony is linked to this supposedly trans-historical or natural (let us say rather naturalized) ideal. (69)

The thrust of Derrida's argument returns the flaws and inconsistencies that Fukuyama argued were endemic to ideology back onto his own 'end of history'. In other words, whilst accepting Fukuyama's argument about the flaws of ideological perspectives, Derrida exposes the ideological facets of liberal capitalism and turns Fukuyama's argument against itself. Within this discreditation, there is a localised concern that has important ramifications when we consider the historical strategies employed within Kent and Slovo's production of The Riots. 
In conversation with Dominic Cavendish, Kent protested that despite everyone believing him to be a 'great champion' of verbatim theatre, for him it was simply a 'means to an end'. (Theatrevoice, November 9, 2011). That end, as he and Slovo have widely articulated, concerns 'giving' a voice to a greater variety of people than would otherwise be heard on particular topics; to grant audiences a chance to examine the contours of that topic in detail; and ultimately to disseminate what they consider to be important information across a broad scope of people. In fact, Kent's only real concession to making a political 'statement' is in the selection of the subject itself, and talking about the various verbatim projects in which he has been involved, he proudly declares that:

We've never been accused of bias, on any of these plays, by any of the press, right or left $[. .$.$] Once we've chosen the subject, then we try and air, the whole spectrum of$ views, I mean obviously, if we're, going to do, the Stephen Lawrence enquiry, by the mere fact we do it, we obviously think that... tackling racism in our society is an important thing... to look at, in depth, so that is our political statement.

(Theatrevoice, November 9, 2011)

This references a belief amongst certain verbatim practitioners that neutrality is a function of legitimacy, and that the further one strives for the former, removing oneself from the history being created, the greater the authenticity of one's eventual work. ${ }^{8}$ In this statement, Kent indicates a profound connection with Fukuyama, whose 'trans-historical standard' is supported by a claim that "'history"... is a deliberate effort of abstraction in which we separate out important from unimportant events.' (138) For Fukuyama, and apparently for Kent, this separation is only possible from a nonideological or stable base from which one can critique the processes of history without falling prey to the inconsistencies and biases endemic to all ideological perspectives. Thus Kent's pride in having never been accused of 'bias' through his (returning to Derrida) accreditation of the 'logic of the empirical event', in the 'unbiased' exploration of the past through the gathering, editing and performing of documentary materials. However, continuing Derrida's argument, Kent is also discrediting the 'logic of the empirical event' in the sense that his emphasis upon the 'logic of the trans-historical event', suppresses what Hayden White calls 'historical emplotment' - the codification of events in a broader historical narrative (3). In other words, Kent claims legitimacy for his theatre because of its absolute grounding within a specific context, through its accurate reproduction of documents or testimonies that relate directly to empirical events. In order to secure this legitimacy, the practitioner and the practice is seen as a 'means to an end' - a channel for commuting material from one place (the subjects) to another (the audiences). Because suppression serves as a criterion for legitimacy, however, the practitioners are prevented from exercising the analytic or critical functions that could position these events within a contextual framework. Instead they operate in a vacuum, which actually reflects what Badiou calls the 'dominant order', an order that, as I will go on to demonstrate, suppresses a given populace by divorcing that populace from history. This is an irretrievably damaging problem that results from conceiving objectivity as a function of historiographic legitimacy. Under this conception, the subjectivity of one's own engagement with history is suppressed, which leads to the destruction of a fundamental aspect of history itself - its temporal and spatial trajectories.

\section{THE END OF THE END OF HISTORY?}

\footnotetext{
${ }^{8}$ See, for instance, Robin Soans' argument that when witnessing a performance of one of his verbatim plays, the audience 'become' the interviewer, directly accessing the testimony of the interviewee. Soans, quoted in Hammond and Steward (2009) Verbatim Verbatim, London: Oberon Books Ltd., pp. 23 - 24.
} 
Thus, where Fukuyama saw the 'end' of history as deliverance from the straightjacket of historical discourses into a neutral 'stability' afforded by liberal capitalism, Badiou perceives this same 'end' but calls it despotic. ${ }^{9}$ This is because the 'end' of history annexes the present from a historical consciousness in which could be found the impetus and potential to 'exit' the established order - an order whose authority and efficacy was challenged and compromised by the explosion of riots and unrests in 2011. In the interviews and articles promoting Holmes' production, Bond imparts a similar sentiment, and in the programme notes he describes a timeline that connects the 'prophetic' elements of his play with the 2011 riots via one of the most visible wings of the neoliberal project in Britain:

Thatcher destroyed political memory and understanding. Instead there is a boredom that craves for new excitement and stimulation because that is all there has ever been. The combination of boredom, the training in cupidity, the lost respect and panic at a new unknown poverty - in fact, at social destitution - is a strange mixture. It penetrates the whole of life. It is deeper, angrier, more destructive - yet in its way more human - than the resentment of fifty years ago. It led to the riots. (Bond: 2011)

Here Bond points to the destruction of political memory and understanding divorcing a modern populace from the historical discourses by which they may otherwise be able to make sense of and overcome the inequities of their societal condition. Boredom fills the gap left by history; a boredom that is all the more dangerous for being un-historical. On the one hand, the history-less victims cannot rationalize, articulate or combat their situation based on established precedents, and on the other, the panic and violence to which this situation gives rise can be dismissed by the ruling elite, as it appears to come from nowhere. This, ultimately, is how David Cameron was able to pass off the England riots as 'criminality, pure and simple' (BBC News, August 9 2011). In a single step therefore, Bond outlines the urgency for history's 'rebirth', concomitantly asserting Saved's role within this, as a text capable of reconnecting the boredom and violence of its performed context with a sense of historical consciousness. Thus, despite (or more likely because of) its temporal ambiguities, Saved is very much a history play in a full sense, both in terms of being 'loaded with history', and in its capacity to offer much needed historicising to the socio-cultural context of its performance.

In writing the play, Bond said that a chief strategy was to push the 'extreme contradictions' of the social structures latent in his initial context - in the play, famously, a baby is stoned to death by a group of young men in order to regain their self-esteem. Bond has called this a 'paradox', one that he is asking his audiences to understand. The systematic erosion of hope and prospect from an entire stratum of society that created this paradox becomes the focus of a wider political critique, which Rabey argues is derived from '[t]he prevalent limitations of choice, particularly regarding selfdefinition and gratification through consumerism and sentimentality' (2003: 80). The critique coalesces into a historical narrative around the destructive potential of advanced capitalism; the narrative then connects the play with its future-other contexts of production, and is ultimately how the revival of a play from 1965 was able to speak to the riots of August 2011. Which is why Saved, though at the level of the textual narrative bereft of many of the typical qualities of a history play, has become historical. Malcolm Hay and Philip Roberts point towards this issue when they talk about the play's flexibility - not in its political objectives, but in the reiterability of its primary concerns:

The question "How did this come about" is not answered by the play. It is left to the

\footnotetext{
${ }^{9}$ It is worth noting that Fukuyama himself has since retracted much of his initial enthusiasm for the 'End of History' project; still his book remains symptomatic of the wider currents in neoliberal thought against which Badiou is pitting his argument. See Francis Fukuyama, 'US Democracy has little to teach China', Financial Times, 17 January 2012, <http://www.ft.com/cms/s/0/cb6af6e8-2272-11e0-b6a200144feab49a.html\#axzz2A1E5vKX6> [Accessed 15 January 2014].
} 
audience. Saved is obviously not about South London, though that is its location. The play is a passionate and logical account of life lived by the social stratum engineered to fit the needs of a consumer-based and technologically-fuelled society. (39)

Rather than try to isolate a particular moment in time through a process of reportage or documentation, in short, Saved is trying to provide a greater sense of the results (past, present and potential) of what Bond and Badiou both call 'the barbarism of modern civilisation' (Bond 1997: 16; Badiou 2012: 14). The play is made applicable to the conditions of its future-other performances by providing a through line, or a narrative thread, between its instances of production. In doing so, it is able to historicise societal conditions that have been divorced from history, a divorce exploited by the dominant order in order to maintain these conditions, and to prevent those subjected to them from escaping their predicament. Which returns us, finally, to the urgent call for what Badiou terms a 'rebirth' of history that Bond has echoed by declaring the increased relevance of his play because 'the future is now here.'

\section{BIBLIOGRAPHY}

Badiou, A. (2012) The Rebirth of History: Times of Riots and Uprisings, translated by Gregory Elliott, London: Verso.

Barthes, R. (1967) 'The Discourse of History' in Keith Jenkins, ed. (1997) The Postmodern History Reader, London: Routledge.

Bauman, Z. (2011) 'The London Riots: On Consumerism Coming Home to Roost', Social Europe Journal, <http://www.social-europe.eu/2011/08/the-london-riots-on-consumerism-cominghome-to-roost/ $>$ [Accessed $15^{\text {th }}$ January 2014].

Boal, A. (2006) Aesthetics of the Oppressed, translated by Adrian Jackson, London: Routledge.

Bond, E. (2011) 'The Bochum Talk: The Third Crisis, the state of Future Drama', September 22 2011, <www.edwardbond.org/Comment/bochumtalk.docx $>$ [Accessed 15 ${ }^{\text {th }}$ January 2014]. (1977) Plays: One, London: Cox \& Wyman Ltd. (2012) 'Riot War Justice and History', <www.edwardbond.org/Comment/riotwarjusticehistory.doc > [Accessed 24 Feburary 2014]. (2011), Saved, London: Methuen.

Brittain, V. and Gillian Slovo (2004) Guantanamo: Honour Bound to Defend Freedom, taken from spoken evidence, London: Oberon.

Derrida, J. (1994), Specters of Marx: the state of the debt, the work of mourning and the new international, London: Routledge.

Fukuyama, F. (1992), The End of History and the Last Man, New York: The Free Press.

Haddow, S. (2014), 'History will eat itself: Rory Mullarkey's Cannibals and the Terror of EndNarratives' in Journal of Contemporary Drama in English. Volume 2, Issue 2, Berlin: De Gruyters.

Hay, M. and Philip Roberts, (1980) Bond: a study of his plays, Trowbridge: Redwood Burn Ltd.

Holdsworth, N. and Mary Luckhurst, (2008) A Concise Companion to Contemporary British and Irish Drama, Oxford: Blackwell Publishing.

Holdsworth, N. (2010) Theatre \& Nation, Basingstoke: Palgrave Macmillan. 
(2014) “"This blessed plot, this earth, this realm, this England”: Staging Treatments of Riots in Recent British Theatre' in Journal of Contemporary Drama in English. Volume 2, Issue 1, Berlin: De Gruyters.

Rabey, D. I. (1986) British and Irish Political Drama in the Twentieth Century, Basingstoke: The Macmillan Press Ltd.

- (2003), English Drama Since 1940, London: Pearson Education Ltd.

Rebellato, D. 'The Limits of Criticism', December $13^{\text {th }} 2011$. $<$ http://www.danrebellato.co.uk/spilledink/2013/3/12/the-limits-of-criticism> [Accessed 5 March 2014].

Slovo, G. (2011), The Riots, London: Oberon Books.

Spencer, J. (1992), Dramatic Strategies in the plays of Edward Bond, Cambridge: Cambridge University Press.

Spivak, G.C. (1999) A Critique of Postcolonial Reason, Cambridge: Harvard University Press.

Stiegler, B. (2013), Uncontrollable Societies of Disaffected Individuals, Disbelief and Discredit, Volume 2, trans. by Daniel Ross, Cambridge: Polity Press. (2014), The Lost Spirit of Capitalism, Disbelief and Discredit, Volume 3, trans. by Daniel Ross, Cambridge: Polity Press.

White, H. (1973), Metahistory: The Historical Imagination in 19th-century Europe, Baltimore: Johns Hopkins University Press.

Žižek, S. (2011), 'Shoplifters of the World Unite' in London Review of Books, <http://www.lrb.co.uk/2011/08/19/slavoj-zizek/shoplifters-of-the-world-unite> [Accessed 24 February 2014]. (2012), The Year of Dreaming Dangerously, London: Verso. 